\title{
FROM PANIC TO CONFUSION TO NEGOTIATION: A REFLECTION FROM EARLY RESPONSE TO COVID-19 IN INDONESIA
}

\author{
Setiadi $^{* *}$; Elan Lazuardi \\ ${ }^{1-2}$ Department of Anthropology, Universitas Gadjah Mada \\ Jl. Bulaksumur, Caturtunggal, Sleman, Daerah Istimewa Yogyakarta 55281, Indonesia \\ 1setiadi_antro@ugm.ac.id; 2elan.lazuardi@ugm.ac.id
}

Received: $04^{\text {th }}$ February 2021/ Revised: $21^{\text {st }}$ March 2021/ Accepted: $22^{\text {nd }}$ March 2021

How to Cite: Setiadi \& Lazuardi, E. (2021). From panic to confusion to negotiation: A reflection from early response to COVID-19 in Indonesia. Humaniora, 12(2), 107-117. https://doi.org/10.21512/humaniora.v12i2.7012

\begin{abstract}
The research reflected on the response to the pandemic that emerged as it happened. It drew attention to the viral aspect of a pandemic, namely how people understood and responded to pandemics using various digital platforms. It questioned the context and reasons for what it called an immeasurable but organized community response to the COVID-19 pandemic. Digital-based research was applied through observing three mainstream digital media (Kompas TV, The Jakarta Post, and Detik.com) and social media (i.e., WhatsApp Messenger and Twitter). Data were analyzed thematically by categorizing the ways people responded to COVID-19 via social media into three thematic phases. In the first phase, digital media was used to voice frustration and disappointment with the government's response. This had sparked public distrust of the government's ability to deal with the pandemic at the national level. The second phase was the confusion phase. The rise of public discussion about the pandemic showed that the public was concerned about the development of the COVID-19 news in the country. The last phase was the negotiation phase. While COVID-19 was rapidly becoming a source of panic and confusion, grassroots initiatives emerged using social media. These initiatives aimed to help reduce panic and reduce socio-economic impacts. The research shows how anthropologists can still pay attention to social relations forged through social media in times of crisis where traditional anthropological fieldwork is nearly impossible. Methodologically, digital anthropology or social media ethnography is gaining momentum to be developed, considering that fieldwork cannot be done in the pandemic era.
\end{abstract}

Keywords: pandemic response, COVID-19, social media, confusion, negotiation, panic

\section{INTRODUCTION}

Back in February 2020, the Indonesian Minister of Health dismissed concerns over impending COVID-19 in the country. This dismissal was made following a statement from a Harvard University researcher, doubting if Indonesia was truly COVID-19 free. Such a response is not exclusive to the Indonesia Health Minister, as several other important government leaders in the world have made similar remarks, essentially downplaying the seriousness of the virus (Crayne \& Medeiros, 2020). As many critics have stated, the Indonesian government's early response to the crisis has been marked by dismissal, rejection, a false sense of security and comfort, late response
(Abdullah, 2020), and a lack of transparency (Riyanto, 2020).

Nevertheless, since then, Indonesia has become one of the countries badly hit by the pandemic (Setiati \& Azwar, 2020), with the number of deaths reaching over 10.000 and daily new cases over 4.000 for the past few weeks (October $\left.3^{\text {rd }}, 2020\right)$. Indonesia has also recorded the second-highest number of confirmed COVID-19 infection cases in Southeast Asia. The WHO has emphasized the importance of maintaining personal hygiene by washing hands, physical distancing, not touching the eyes, nose, and mouth, avoiding crowded places, following good respiratory practices, as well as self-quarantining if necessary. More recently, the WHO has also advised 
individuals to wear fabric facemask in public. Many countries have combined various non-pharmaceutical prevention and intervention strategies to reduce the spread of COVID-19 (Nicola et al., 2020), such as addressing both the needs of the poor and vulnerable groups (Olivia, Gibson, \& Nasrudin, 2020).

While the WHO has not officially recommended lock-down, several countries have adopted various forms of lock-down. China, for instance, closed the border of Wuhan and several other cities in Huabei Province - the province where Wuhan is the capital of - and restricted the movement of its population from January to early April 2020. Italy entered into a national quarantine between March and May 2020. Similarly, after closing its border for a few days, New Zealand entered into a nationwide lock-down period on March $25^{\text {th }}, 2020$.

Neighboring Asian countries such as Vietnam immediately placed travel restrictions and social distancing early on, while South Korea has aggressively conducted testing and contact tracing for early detection (Perdana, 2020). These different responses to the pandemic demonstrate that despite being a global phenomenon, its responses are local, depending on the local government, socio-economic, and cultural contexts (Friedler, 2020; Shaw, Kim, \& Hua, 2020).

In the past year, scholars have critically analyzed the gaps between Indonesian policy response and its implementation on the ground (Korwa et al., 2020; Riyanto, 2020; Yuda, Damanik, \& Nurhadi, 2020), including in the area of crisis communication (Aziz \& Wicaksono, 2020), local pandemic responses (Davies, 2020; Ghani \& Sitohang, 2020; Semedi, 2021), and the socio-economic impacts of the pandemic and the challenges ahead (Sparrow et al., 2020). While such discussions are useful in understanding COVID-19 and its official and unofficial responses, little attention is paid to how people understand and respond to COVID-19 using various digital platforms.

Social media is positioned strategically not only in the context of fast dissemination of knowledge, including related to COVID-19 (Chan et al., 2020), but also as social capital (Elgar, Stefaniak, \& Wohl, 2020) and a place for the people's aspiration to criticize a policy carried out by the government (Zahra, Purnomo, \& Kasiwi, 2020). On the other hand, social media is often considered in the ways it negatively impacts misinformation (Cuello-Garcia, Pérez-Gaxiola, \& Amelsvoort, 2020; Gruzd \& Mai, 2020). Considering Indonesia as one of the biggest countries in terms of the number of users of social media (Herman \& Mononimbar, 2017), it is important to look at the ways COVID-19 is being talked about by Indonesians on various social media platforms.

A number of very recent studies have included analysis on the ways COVID-19 is discussed in social media. In a recent publication, for instance, Nadzir (2020) has traced the political and social structures that enable conspiracy theories around COVID-19 to gain currency in Indonesia using a number of social media-related case studies, such as Jerinx and Anjitwo public figures who are both accused of spreading hoaxes. In another research, Budi and Pamungkas (2020) look at the ways political partisanship is changed - or even possibly shaken - in the time of COVID-19 through the use of social network analysis of Twitter. In the time of COVID-19, affiliates of the Islamic State (ISIS) in Indonesia have also been repurposing social media messengers such as Telegram for their interests (Permono, Nurish, \& Muta'ali, 2020).

The present research has one main implication. Digital anthropology, or ethnographies of social media, in particular, have not gained momentum in the Indonesian context, although there have been several studies conducted in Indonesia in the past few years (Ansori, Febrian, \& Ramadhan, 2017; Nisa, 2018; Slama, 2018). There is perhaps no better time to strengthen this field as another avenue anthropologists can contribute to the academic and public discussion of COVID-19 in Indonesia and the use of digital anthropology in Indonesia for broader global readers. Describing and analyzing the phenomenon of the COVID-19 crisis are seen as significant contributions that can be offered by the anthropological perspective to the current crisis (Schmid, 2020).

Contributing to this growing body of research in social media and how it is used to respond to the crisis, in this research, the researchers reflect on the public responses to the emerging pandemic as it unfolds. Through the lens of social media, the researchers draw attention to the viral aspect of the pandemic not only because of the scale with which the pandemic spread but also because the ways it is understood and responded to it have made the pandemic a highly mediatized event. Through social media analysis, the researchers interrogate the contexts and reasons for what is called 'unmeasured but organized community responses' to the COVID-19 pandemic. In focusing on the forms of socio-cultural responses mediated by different digital platforms, the researchers also demonstrate the possibilities of using an anthropological lens to learn about the pandemic as it unfolds through social media when access to the 'field' - as it is understood in the conventional anthropological sense - is limited.

\section{METHODS}

In this COVID-19 times, field-based research that is the center of traditional anthropological research faces a crisis. Anthropologists and ethnographers around the world are thinking of using old and new ways in doing research, including what is perhaps a new rise of digital-based research. Thus, digital ethnography has gained renewed interest in this time (Góralska, 2020). Using this approach, research can be conducted from anywhere without direct face-toface contact with research subjects.

Using digital media as a field or data source is hardly a novel way of doing anthropological fieldwork (Coleman, 2010; Miller, 2018; Miller et al., 2019). 
Similarly, social media ethnography is not new either (Postill \& Pink, 2012). However, because the intention is to reflect, rather than doing a complete 'proper' anthropological fieldwork, data collection for the research is not conducted systematically.

Reflection in the research is based on observation on three mainstream digital media (such as online newspaper - KompasTV, Detik, and The Jakarta Post, which are often used alongside their official YouTube channel) as well as two forms of social media such as specific WhatsApp groups, and particular accounts on Twitter (such as kawalcovid19). The lead researcher is a member of a number of professional and neighborhood-based WhatsApp groups from which observation for the research is sourced.

Data are collected from mid-March to May 2020 by finding, observing, and recording various things within the five digital media platforms mentioned previously. Several keywords are used in collecting data, including the term corona, COVID-19, the Indonesian government, the government's response, community self-sufficiency, local capacity, and local government response.

Data are analyzed thematically to find patterns in the ways members of the public engage with government policies and COVID-19 in general. Excerpts from chats (in the case of WhatsApp groups), comments from online news sites (in the case of Detiknews), posts and comments (in the case of Twitter), and comments in official YouTube channel of KompasTV are all compiled in a single word document and categorized thematically according to a common thread.

\section{RESULTS AND DISCUSSIONS}

In the first section, the researchers discuss COVID-19 as a kind of mediated event. Globally, almost no countries have been spared by SARSCoV-2, a genome of coronavirus that caused COVID-19. Firstly, detected in December 2019 in Wuhan, China, the virus has since travelled from city to city; from China to almost all countries. By January $30^{\text {th }}, 2020$, the World Health Organization (WHO) announced COVID-19 as a public health emergency of international concern, its highest level of alarm, before declaring it as a pandemic on March 11 $1^{\text {th }}, 2020$.

"The COVID-19 pandemic ushered people, animals and micro-organisms into the disjointed 'time of the epidemic', a global event which doubtlessly prompted the greatest ever number of rapid commentaries from anthropologists." (Roth, 2020)

Since then, COVID-19 has already infected over 34 million people and caused the death of over 1 million people worldwide (October $\left.3^{\text {rd }}, 2020\right)$. Nonetheless, COVID-19 is hardly the first pandemic in the history of humankind to cause such a global catastrophe. Early in 2020, when the scale of COVID-19 impact is limited to a few countries such as China and South Korea, comparisons have been drawn between COVID-19 and past pandemics such as the $1918 \mathrm{flu}$ (also known to be the deadliest flu) (Pitlik, 2020). The death toll of the 1918 flu pandemic is estimated to be as high as 50 million people worldwide. Comparisons have also been made between COVID-19 and other respiratory diseases caused by different types of coronavirus, which led to two distinct pandemics, i.e., SARS and MERS (Petersen et al., 2020).

Then, how is COVID-19 different? Recent works of literature have drawn attention to the microbiological, clinical, and epidemiological characteristics of COVID-19, all of which contribute to making COVID-19 a distinct pandemic. For instance, the mortality rate of both COVID-19 and SARS tends to be higher for people older than 70 years. However, an asymptomatic person infected with SARS-CoV-2 is already infectious, which is different from SARS-CoV (Petersen et al., 2020).

The researchers are more interested in the social context within which this pandemic occurs as another key element that makes COVID-19 different from past pandemics. As a historian of medicine, Lukas Engelmann (2020) has written that the history of COVID-19 is written daily, if not hourly, on social media, making it the spectacle of real-time surveillance.

In this way, the pandemic is understood as a historical event (Peckham, 2020). The research extends Engelmann's take in viewing COVID-19 as the spectacle of real-time surveillance to include the broader ways COVID-19 is made into a mediated event. Unlike other pandemics, COVID-19 benefits from how connected the world currently lives in. Governments in different parts of the world try to prevent the further spread of the virus by closing their borders as soon as it is known how COVID-19 is transmitted.

Some countries have not taken such actions early enough. In addition to connections made by travels, the contemporary world system is connected through the production, consumption, and distribution of media. Giddens (1990) has argued that worldwide social relations have been intensified and refers to this process as globalization. The technological advances of digital media have contributed to the scale and impact of such intensified social relations.

In the context of COVID-19, as Engelmann points out, the researchers engage with COVID19related news through media in a number of different ways, including following the hashtag (\#COVID-19) on Twitter, participating in WhatsApp groups conversation, reading the newspaper, watching the news broadcast on television, listening to news podcast about COVID-19, and so on. Apart from involvement in COVID-19 related activities held on the ground (face-to-face), these different modes of engagement have made COVID-19 a highly mediated event.

In viewing COVID-19 as a mediated event, the 
researchers see 'event' as 'happenings' or 'things that occur' (Dayan, 2005; Scannell, 2002) or 'interruptions of routine' (Dayan \& Katz, 1992). While initially used to analyze ceremonial events such as the royal wedding or the Pope's travel, media events are also used to examine catastrophic events, such as disasters (Scannell, 2018). In viewing an event like this, the COVID-19 pandemic that is currently unfolding is an event in itself. It is common for media scholars to discuss about events and particularly their effects after the occurrence. In writing about COVID-19 as an event, the research is rather unconventional. The research intends to reflect on the event as it happens.

By mediated event, it means that what is known about COVID-19 is often brought people through media, such as televised news, social media feeds, or conversations on private social messenger groups. In the context of Indonesia, this is particularly relevant as the country is reported to have one of the highest users of social media (Lim, 2013).

Most Indonesians, irrespective of age, have access to the internet to use social media. Social media is generally used for various communication purposes, including personal, social, and professional. However, the researchers do not imply that COVID-19 is solely experienced through media as people worldwide continue to feel the impact of the pandemic. Job loss and reduced income are common (Gonzalez et al., 2020; Kansiime et al., 2021; Purnamasari et al., 2020), so are caring for or even losing family members to COVID-19.

Lindenbaum (2001), in her 2001 review on the kuru epidemic, a fatal incurable neurodegenerative disorder with body tremors as one of its most common symptoms in Papua New Guinea, and bovine spongiform encephalopathy epidemic (also known as the mad cow disease) in Europe, has argued that studying epidemics allows people to understand the relationships among cultural assumptions, institutional forms, and state of minds. This section discusses how the public engages with COVID-19 in Indonesia, particularly in response to government actions (or lack thereof), to unpack the underlying cultural assumptions and state of mind behind such engagement. Like any other social phenomena, epidemics follow a common dramaturgic form (Lindenbaum, 2001) with a start (often in limited geographical scale), an increase, and a crisis before they eventually drift towards closure (Rosenberg, 1992).

What follows is a discussion structured into three phases that are deemed crucial for the research's purpose: the initial frustration and disappointment phase, the confusion phase, and finally, the negotiation phase.

Firstly, it will show how Indonesians initially responded to the news related to the pandemic with expressions of panic, disappointment, and frustration. On March $2^{\text {nd }}, 2020$, President Jokowi announced the first two cases of COVID-19 (Gorbiano \& Fachfiansyah, 2020). In January and February 2020, Indonesian media started to broadcast news about the spread of COVID-19, particularly when it started in China. The official announcement of the first Indonesian COVID-19 cases followed several controversial statements by government officials, which already drew much criticism (Riyanto, 2020).

Government officials, including Vice President Ma ruf Amin, Health Minister Terawan, and Maritime and Investment Minister Luhut Pandjaitan, were quoted in statements to media, essentially downplaying the seriousness and gravity of the pandemic. Maritime and Investment Minister Luhut Pandjaitan, for example, said that according to their modeling, COVID-19 would not last in Indonesia due to the hot weather, although it was not very clear whose and which modeling he was referring to (Hakim, 2020). Perhaps ironically, the announcement of the first two cases came two weeks after the government launched a tourism-related policy to assist with the looming economic impact of the global pandemic (Antara News, 2020).

Discounted airplane tickets were provided to 10 major tourist destinations (Marisca, 2020). Similarly, the Health Minister stated that while warding the virus off was easy (Almuttaqi, 2020), the hard one was to deal with hoaxes. However, on another occasion, he stated that the power of prayer would prevent Indonesia from the virus. They said that while looking at Pancasila, Indonesians have the almighty God. Other countries may protest, let them, but this country's right that relies on God. As long as people rely on God, that is what they have now. It does not need to be ashamed of relying on God (Gorbiano \& Fachriansyah, 2020).

However, narratives around COVID-19 had developed in Indonesia before this announcement was made. One of the news that gained traction in Indonesia was the Diamond Princess ship case.

On January $20^{\text {th }}$, the ship departed from Yokohama, Japan, on a roundtrip cruise to Southeast Asia. A man who had previously been in Guangdong, China, boarded the ship before embarking on Hong Kong. The man subsequently tested positive for COVID-19.

The slow response to preventive measures caused an outbreak, leading to more than 400 positive cases among the ship passengers and crews. The government of Indonesia evacuated 69 Indonesian crews from the ship in early March. The case drew media attention before Indonesia even had its first official case.

Indonesians responded to the Diamond Princess case with arguments using either public health perspective or religious belief. Netizen's responses varied, ranging from wanting to close all overseas flights or asking President to close international flights first, to a more extreme comment, such as to quarantine those who just came from abroad 14 days before entering the community. Another user referred to a hadith from Prophet Muhammad:

"It means that if you hear there's an outbreak in a region, then you should not enter it. However, 
if an outbreak occurs where you live in, then don't leave that place." (March 15 ${ }^{\text {th }}, 2020$ )

Based on these responses alone, it was evident how concerned the public was over the spread of COVID-19, given the massive coverage of Wuhan, China. By participating in such public discussion in the internet space, netizens voiced their disapproval of government response as they deemed it too slow and lacked urgency and seriousness.

Lack of urgency in handling the COVID-19 pandemic was also apparent in several local government responses. Prabumulih City can be an illustration. In a viral video, the mayor Ridho Yahya was seen telling a journalist that he did not plan to close schools in response to COVID-19.

The video was shared on social medias, such as Twitter, garnering public attention and criticism. Similarly, in another video published on YouTube on March $7^{\text {th }}$ - five days after Jokowi announced the first COVID-19 cases in Jakarta, Ridho was quoted through another statement:

"We don't ask the municipal government employees and school students to not go to work and school for now. Because if I do it now, it will cause public unrest. (I do this) to appease the community. People work in food stalls everywhere; it will be quiet too (if I close schools and government offices). No, this [COVID-19] is normal, it's a disease. It seems like they no longer believe in God. The disease was given by God, tested by God. We believe that God is the best member. It's a lesson for us. Don't stop doing daily prayer, it's not allowed. We can't; that's shameful. All religious activities still have to go on. The government will cover the cost for those who are sick." (Zulkaedar, 2020).

The mayor's statement shows that the economic impact of suspending face-to-face activities is more important than the health effects of the epidemic. Such a position was not exclusive to the mayor of Prabumulih but was also shared by other government official statements, including the Governor of North Sumatera. In a video uploaded by Metro TV on their official YouTube channel on $16^{\text {th }}$ March, the governor said that school exams would proceed as scheduled and that face-to-face classes would not be suspended. Like the Prabumulih case, the local government made this decision because there were no or very insignificant number of COVID-19 cases in their jurisdiction. Responding to Edy's statement, netizens also deemed his response to be lacking. The following excerpts are some of the interesting comments on the video.

Bricky: "You moved too slow, no one wants to vote for you in the next period of presidential election."

Edborah Saragih: "When a comedian becomes a state official."
Aramstar Studios: "Slow and dissident."

Pakistani: "It's OK. All Indonesian schools seems to play around, really." (Gusti, 2020).

Secondly, moving on from the initial phase of disappointment and frustration, after the announcement of the first two cases, discussion about COVID-19 appears as an everyday staple for Indonesians, including or perhaps especially on social media. On the one hand, the amount of public discussion about the pandemic shows that people pay much attention to the development of COVID-19 news in the country. On the other hand, the discussion indicates confusion among people.

This is unsurprising for two reasons. First, the central and local governments respond with different and sometimes divergent policies, at least in the beginning. While this is to be expected given different epidemiological characteristics and development, this leads to comparison. For instance, in the comment section of the news video quoted earlier, user Kamar offline has written:

"The hospitals in the regency/city should manage and prepare its capacity, equipment, and health workers to accommodate COVID-19 patients. Don't be embarrassed to take the lead of DKI Jakarta Government."

Second, the government is considered to be less responsive in handling this pandemic. The public is confronted with a counter-productive attitude even after the central government released a physical distancing policy. The public is presented by non-compliance among government officials who are considered to lead by example. The account of Indonesian Corruption Watch has questioned the Regional Police Chief of North Sulawesi, who was captured bicycling around the city (Al-Ayyubi, 2020).

"Dear Police Chief of North Sulawesi and Mayor of Manado, will the appeal of the president and the Chief of the Indonesian National Police to prevent the spread of COVID-19 with social distancing not applicable to officials? What a pitiful state. There's a paradox between the appeal and the reality. How will society obey if the leaders do not give an example? What are the medical workers who are dealing with this pandemic supposed to be feeling now? What about the Christians who cannot worship at church tomorrow, are advised to stay at home, while the officials are riding bicycles casually in a group like this? So confusing." (Santoso, 2020).

At the local level, the emergency response started to emerge in mid-March. The neighborhood was seen to be one of the frontlines of such a response. Many started to organize by limiting access to their neighborhood by constructing makeshift barriers 
and placing guards to monitor visitors (Lazuardi, 2020). Some of these neighborhoods responded to the recommendation to use village funds for COVID-19 prevention and treatment. In several WAGs in which the lead author is part, members reported activities in their village.

"Today the spraying of disinfectants in the village has begun, the versatile buildings have been provided. Now, the activity's heading to Mosque A. Salute to the emergency team for COVID-19." (Sasti, Researcher, 58 years old. March 20 $\left.{ }^{\text {th }}, 2020\right)$.

Spraying disinfectant was not limited to a building or outdoor areas but also humans. Others started giving their opinions about the dangers of disinfectant, saying:

"Spraying disinfectant is dangerous because it carries carcinogens, a cancer-causing agent." (Syah, Researcher, 45 years old. March $20^{\text {th }}$, 2020).

However, such warning was rarely confirmed; people's enthusiasm for spraying dominated the discussion. People distributed instructions to make a DIY disinfectant. A few months into the pandemic, shops and supermarkets were quick to empty their selves off. Such enthusiasm appeared to mirror the general trend of government agencies. The government intensified the social distancing movement and restrictions on activities in the formal institutions, but they did not get the appropriate response. Work From Home (hereafter: WFH) was often interpreted as a vacation.

Many people do not understand and do not care about the danger of this pandemic. Observations from neighborhood WhatsApp group where the number of elderly households is significantly higher than the young ones show that the policy for WFH is instead used by people who live in the city to return to their villages. A WhatsApp group participant has said:

"One family came from Jakarta with his friends by car. They just came. He's Mr. S's brother, P's father. It was Mr. S's son, Mrs. P and her husband, Mr. B, as well on the other day" (YA, Public Welfare worker, 58 years old. May $20^{\text {th }}$, 2020).

The phenomenon of pulang kampung (or returning to hometown) quickly garners public attention and is often seen as a dilemma. On the one hand, people are concerned that without any measure, this phenomenon would increase the number of COVID-19 cases in smaller cities. On the other hand, informal workers in big cities such as Jakarta increasingly face difficulties due to job or income losses.

Death is one of the most prominent topics of discussion. Rather than being understood as a signal of the importance of preventive action, news about death sparks discussion about the actual cause. Kompas TV has reported that a family of a suspected patient who died in Kolaka, Sulawesi, is determined to bring the body home to be buried. The local head of the COVID-19 emergency team has told the journalists:

"The patient died. We received the information after the body was brought on the way home. The patient has died and has been treated as a PDP, wrapped up, and treated as a PDP based on the procedure. The family refused and picked him up in a private car and brought back to Kolaka. When the body of the family arrived at the funeral home, many welcomed the corpse. Is there any procedure implemented regarding the burial procedure? The team couldn't intervene. The process was so fast, bathed, and immediately taken to the cemetery. We were not involved at all. The family opened the plastic and did the burial as a normal condition. Now our team's effort is to take further action, for example advocating isolation while awaiting the progress." (Source: https://youtu.be/ ckG0OSxdjXc uploaded 24 March 2020 by Kompas TV)

The Jakarta Post is described as:

"Patient with positive COVID-19 from Kolaka died yesterday at the Bahteramas Hospital. The hospital officers were about to bury him, but the patient's husband brought her home. As he arrived at home, he and his family opened the plastic bag covering the patient's body and bathed (the body) again. Meanwhile, WHO standard to deal with bodies [of COVID-19 patients] said that the bodies should be directly cremated. So, if there were family or people around Kolaka, the people should be more careful when communicating with them, because this is an A1 information that must be distributed." (News Desk, 2020).

This is in stark contrast to a description of another death in Jakarta. An online media, Detiknews, has interviewed Daniel, one of the relatives of the dead. The latter has said that a team of six people wearing blue hazmat from the local health office delivered the dead body to the burial place in the middle of the night. The process following the arrival of the dead body is described as quick without other people except for family members and the burial team present. The coffin is sprayed with disinfectant before the burial. Daniel has further elaborated:

"There was another man dressed in striped, stopping the family members to avoid getting near the grave and stand at least 30 meters (from the grave). We could only move forward 
after the coffin was covered by the ground. It took about 20 minutes." (Alfons, 2020).

Lastly, following the first two kinds of responses, i.e., frustration and confusion as COVID-19 rapidly become a source of panic and confusion, the researchers look at a different kind of response where people try to negotiate between the two initial responses using two examples. Following what the public deemed as delayed responses, a number of grassroots initiatives have emerged. Such initiatives aim to contribute to lessening the panic and reducing the socio-economic impact. In Yogyakarta, for instance, the grassroots movement has begun to respond to the possible negative impact of social restriction as early as the end of March. By March 27, 2020 , three community movements have emerged on social media to provide food for those in need, i.e., \#dapuraksishare movement (1-30 April), Jogja Food, and SONJO. These initiatives are often established in a fairly quick manner.

For instance, the time between SONJO formation and its first action takes no longer than 48 hours. The logic behind SONJO formation is relatively simple. The founders believe that many people need help, both those who are vulnerable and at-risk (demand). In addition, many institutions and people with higher income are willing to help (supply). SONJO acts as the medium through which demand meets supply. Groups like SONJO uses social media and private messaging services such as WhatsApp groups to invite different elements of Yogyakarta's people.

SONJO establishes an information system and database to record important details, including who needs helps, who can provide solutions, where assistance is provided, and who receives aid.

The impact is an optimization of resource allocation related to donation. This message illustrates the way SONJO members share information through WhatsApp groups:

"Dian canteen on Jalan Diponegoro provides free meals for those who have been affected by this pandemic. Only 10.000 rupiah per meals from benevolent customers and it will be distributed to those in need. Just leave 10.000 rupiah aside and the packaged foods are made for those who live in the surrounding area of the monument. Please fill with number 01 at the end of the amount, for example 10.001, 50.001, etc. One pack of food will lengthen the life of our brothers and sisters who have been affected by this pandemic. We need your kind help. Here's our account number: BCA 0051XXXXX. Telephone +62 813-XXXX."

Another well-known movement initiated during the pandemic is kawalcovid19, founded by a collective of researchers including epidemiologists, data scientists, and policy analysts. Before launching its website, the collective made its Twitter account to provide COVID-19 related information to the public. Since $6^{\text {th }}$ March (a mere few days after the first cases), @kawalcovid19 has provided daily updates of the COVID-19 situation, including daily new cases and cases per province. Using data collected from various sources, the collective aims to encourage and advocate for data transparency, crisis communication, and evidence-based information, even before the Indonesian government starts to do so.

Recently, through its Twitter account, it has also reported discrepancies between local and central government data. In addition to Twitter, the collective maintains a website that has quickly become one of the main references for people to keep updated with COVID-19 related news.

In addition to grassroots movements such as SONJO and@kawalcovid19, awareness about the importance of mental health has been another focus that both people and the government pay attention to. While awareness of mental health began to increase in Indonesia before the pandemic, the pandemic and its related social restriction have highlighted the importance of maintaining one's mental health even more. For instance, a video from YouTube titled Relaksasi untuk Ketenangan, Kedamaian, dan Kesehatan (Relaxation for Calmness, Peace, and Health) is shared on a WAG on March 27, 2020 at 05.19 AM.

The original video itself is already viewed 27.244 times. Since it was uploaded on $20^{\text {th }}$ March, the 26-minute video has been viewed 399.193 times (per $12^{\text {th }}$ November 2020) and drawn 63 comments. The majority of commenters thank the uploader, who described himself as a leading expert in mind technology in Indonesia, for helping them improve their emotional wellbeing, particularly in this trying time. For instance, user Idham Husen has said:

"Thank you, Mr. Adi, I'm suffering from anxiety disorder, (I) often feel like I am getting sick. Listening to this audio helps me relax and be inspired ..."

Another user, Melati Asri, has similarly commented:

"A friend of mine unintentionally told me to do self-healing in the midst of COVID-19 pandemic. I've tried it before in 2005, and the past week I've been trying it again. Only a slight difference. Knowledge from Mr. Adi ensures that I can do [the relaxation] again to improve my immune system."

These two examples illustrate the ways people negotiated with COVID-19 in their daily lives using a different digital platform. Groups like SONJO capitalize on social messengers such as WhatsApp to bring attention to the needs of the socially marginalized group. They use their private network to mobilize financial resources to help people in need. Similarly, 
@ kawalcovid19 makes it their mission to inform the public with correct and up-to-date information related to COVID-19 in Indonesia.

While digital media studies have often focused on the effectiveness of social media for political activism, such in the case of Spain (Postill, 2014), anthropologist Liana Chua also calls for anthropologists to use social media to investigate the multiple scales and shades of participation on social media (Chua, 2018a). In her nod to McLagan, anthropologists can look for the ways particular participants are assembled and produced through ethnographies of social media. By doing so, 'participation' through social media is seen to take many different forms (scale and shades); hence, the study on social media is not limited to activism only. Thus, the ways some Indonesians responded to COVID-19 related news appear to be 'small acts' of participation (Chua, 2018b).

\section{CONCLUSIONS}

Digital anthropology has been used to raise questions about what it means to be human in this contemporary world. Digital media has become entangled in our everyday lives, including as a means through which we pass moral judgment. Throughout the research, the researchers have mapped out how social media, digital news outlets, and private messaging apps (digital media) have been used and repurposed to respond to the disruption of everyday life following the COVID-19 pandemic. In this way, the research has contributed to understanding how people respond to COVID-19 using various digital platforms.

Indonesia is one of the largest markets for social media, with both YouTube and WhatsApp having the highest penetration rates; hence it is unsurprising that even before the first case, COVID-19, was found in Indonesia, people have engaged in different ways with COVID-19 related news. The research has grouped how people engage with (respond to) COVID-19 through social media in three thematic phases. Digital media has been used to voice frustration and disappointment over government responses (or lack thereof). When some government figures appear before the public eyes with statements that are often contradictory with international (scientific) authorities, people are frustrated.

This fuels public distrust over the government's capacity in handling the pandemic at the national level. Similarly, when government figures such as in the case of Mayor Prabumulih launched local policy, which was contradictory with the national policy with regards to large-scale social restriction, people were once again angered. When it becomes apparent that COVID-19 is (and still is) a threat to public health with the rising rates of new infection and death, Indonesian social media users keep an eye on how the different levels of government dealt with the crisis. The researchers have highlighted how news about the burial of COVID-19 patients is met with confusion by social media users.

Throughout the research, it has shown how anthropologists can still pay attention to social relations in the middle of a crisis where traditional anthropological fieldwork is almost impossible. During the COVID-19 outbreak, many Indonesian people participated in multiple social relations by engaging with news related to the pandemic and various aid programs at the community level. Nevertheless, this research has several limitations. First, data collection is conducted in a fairly short time (March-May 2020); hence, it only covers limited ranges of conversation about COVID-19 occurring in different digital platforms. Second, as the researchers have noted in the methods section, as the intention is to make reflection research, the researchers do not collect data systematically as social media ethnography is purported to be by digital ethnographers.

For future research, the researchr has one main implication. Digital anthropology, or ethnographies of social media, in particular, have not gained momentum in the Indonesian context, although there have been several studies conducted in Indonesia in the past few years. There may be no better time to strengthen this field as another avenue anthropologists can contribute to the academic and public discussion of COVID-19 in Indonesia and the use of digital anthropology in Indonesia for broader global readers. Describing and analyzing the phenomenon of the COVID-19 crisis are seen as significant contributions that can be offered by the anthropological perspective to the current crisis.

\section{REFERENCES}

Abdullah, I. (2020). COVID-19: Threat and fear in Indonesia. Psychological Trauma: Theory, Research, Practice, and Policy, 12(5), 488-490. https://doi.org/10.1037/ tra0000878.

Al-Ayyubi, S. Al. (2020). Kapolda Sulut gelar sepeda santai saat wabah corona, ICW minta dicopot. Retrieved from https://m.solopos.com/kapoldasulut-gelar-sepeda-santai-saat-wabah-corona-icwminta-dicopot-1053342.

Alfons, M. (2020). Meninggal karena corona, keluarga ceritakan proses penguburan jenazah di TPU. Retrieved from https://news.detik.com/ berita/d-4952230/meninggal-karena-coronakeluarga-ceritakan-proses-penguburan-jenazah-ditpu.

Almuttaqi, A. I. (2020). Kekacauan respons terhadap COVID-19 di Indonesia. THC Insights, 13, 1-7.

Ansori, S., Febrian, F., \& Ramadhan, H. A. (2017). Youth Personhood@CROSSROAD: A virtual ethnography of an asymmetrical relation between digital natives and digital immigrants in Indonesia. Antropologi Indonesia, 37(2), 103-117. https://doi.org/10.7454/ ai.v37i2.8769.

Antara News. (2020). Presiden: Diskon tiket pesawat tidak akan perluas sebaran virus corona. Retrieved from https://www.antaranews.com/berita/1329942/ 
presiden-diskon-tiket-pesawat-tidak-akan-perluassebaran-virus-corona.

Aziz, M. S., \& Wicaksono, M. A. (2020). Komunikasi krisis pemerintah Indonesia dalam penanganan COVID-19. Masyarakat Indonesia: Jurnal IlmuIlmu Sosial Indonesia, 46(2), 194-207. https://doi. org/10.14203/jmi.v46i2.898.

Budi, A., \& Pamungkas, W. A. (2020). Partisanship in crisis: Public response to Covid-19 pandemic in Indonesia. Jurnal Ilmu Sosial dan Ilmu Politik, 24(1), 15-32. https://doi.org/10.22146/jsp.56443.

Chan, A. K. M., Nickson, C. P., Rudolph, J. W., Lee, A., \& Joynt, G. M. (2020). Social media for rapid knowledge dissemination: Early experience from the COVID-19 pandemic. Anaesthesia, 75(12), 1579-1582. https://doi.org/10.1111/anae.15057.

Chua, L. (2018a). Too cute to cuddle? "Witnessing publics" and interspecies relations on the social mediascape of orangutan conservation. Anthropological Quarterly, 91(3), 873-903. https://doi.org/10.1353/ anq.2018.0043.

Chua, L. (2018b). Small acts and personal politics: On helping to save the orangutan via social media. Anthropology Today, 34(3), 7-11. https://doi. org/10.1111/1467-8322.12432.

Coleman, E. G. (2010). Ethnographic approaches to digital media. Annual Review of Anthropology, 39, 487-505. https://doi.org/10.1146/annurev. anthro.012809.104945.

Crayne, M. P., \& Medeiros, K. E. (2020). Making sense of crisis: Charismatic, ideological, and pragmatic leadership in response to COVID-19. American Psychologist, 76(3), 462-474. https://doi. org/10.1037/amp0000715.

Cuello-Garcia, C., Pérez-gaxiola, G., \& Amelsvoort, L. Van. (2020). Social media can have an impact on how we manage and investigate the COVID-19 pandemic. Journal of Clinical Epidemiology, 127, 198-201. https://doi.org/10.1016/j.jclinepi.2020.06.028.

Davies, T. P. (2020). From the bubble to the hearth: Social co-presence in the era of COVID-19 in Asmat, Indonesian Papua. Special Issue: Oceanic Societies in COVID-19, 90(S1), 14-20. https://doi. org/10.1002/ocea.5259.

Dayan, D. (2005). The Pope at reunion: Hagiography, casting, and imagination. In E. W. Rothenbuhler \& M. Coman (Eds.), Media Anthropology (pp. 165175). California: SAGE Publications.

Dayan, D., \& Katz, E. (1992). Media events: The live broadcasting of history. Cambridge: Harvard University Press.

Elgar, F. J., Stefaniak, A., \& Wohl, M. J. A. (2020). The trouble with trust: Time-series analysis of social capital, income inequality, and COVID-19 deaths in 84 countries. Social Science and Medicine, 263, 113365. https://doi.org/10.1016/j. socscimed.2020.113365.

Engelmann, L. (2020). \#COVID19: The spectacle of real-time surveillance. Retrieved from http:// somatosphere.net/forumpost/covid19-spectaclesurveillance/.
Friedler, A. (2020). Sociocultural, behavioural and political factors shaping the COVID-19 pandemic: The need for a biocultural approach to understanding pandemics and (re)emerging pathogens. Global Public Health, 16(1), 17-35. https://doi.org/10.1080 /17441692.2020.1828982.

Ghani, M. W., \& Sitohang, M. Y. (2020). Reaksi penduduk di wilayah minim akses pada fase awal di pandemi COVID-19. Masyarakat Indonesia: Jurnal IlmuIlmu Sosial Indonesia, 46(2), 168-179.

Giddens, A. (1990). The consequences of modernity. Cambridge: Polity Press.

Gonzalez, D., Zuckerman, S., Kenney, G. M., \& Karpman, M. (2020). Almost half of adults in families losing work during the pandemic avoided health care because of costs or COVID-19 concerns. Retrieved from https://www.urban.org/sites/default/files/ publication/102548/almost-half-of-adults-infamilies-losing-work-avoided-health-care-becauseof-cost-or-covid-19-concerns_1.pdf.

Góralska, M. (2020). Anthropology from home: Advice on digital ethnography for the pandemic times. Anthropology in Action, 1(1), 46-52. https://doi. org/10.3167/aia.2020.270105.

Gorbiano, M. I. \& Fachfiansyah, R. (2020). "It's our nation's right to rely on the Almighty": Minister justifies calling for prayers in coronavirus battle. Retrieved from https://www.thejakartapost.com/ news/2020/02/17/its-our-nations-right-to-rely-onthe-almighty-minister-justifies-calling-for-prayersin-coronavirus-battle.html.

Gruzd, A., \& Mai, P. (2020). Going viral: How a single tweet spawned a COVID-19 conspiracy theory on Twitter. Big Data \& Society, 7(2), 1-9. https://doi. org/10.1177/2053951720938405.

Gusti, M. (2020). Sumut belum liburkan sekolah, Edy Rahmayadi: Kalau diliburkan, anak bisa jalanjalan. Retrieved from https://www.kompas.tv/ article/71564/sumut-belum-liburkan-sekolah-edyrahmayadi-kalau-diliburkan-anak-bisa-jalan-jalan.

Hakim, R. N. (2020). Luhut: Dari hasil modelling, virus corona tak kuat hidup di cuaca Indonesia. Retrieved from https://nasional.kompas.com/ $\mathrm{read} / 2020 / 04 / 02 / 15275601 /$ luhut-dari-hasilmodelling-virus-corona-tak-kuat-hidup-di-cuacaindonesia.

Herman., \& Mononimbar, D. A. (2017). Indonesia fifthlargest country in terms of Twitter users. Retrieved from https://jakartaglobe.id/news/indonesia-fifthlargest-country-in-terms-of-twitter-users/.

Kansiime, M. K., Tambo, J. A., Mugambi, I., Bundi, M., Kara, A., \& Owuor, C. (2021). COVID-19 implications on household income and food security in Kenya and Uganda: Findings from a rapid assessment. World Development, 137, 105199. https://doi.org/10.1016/j.worlddev.2020.105199.

Korwa, J. R. V, De Fretes, D. R., Wambrauw, M. S. F., Yumame, J., Sanggenafa, C. O. I., Shintasari, R., \& Snanfi, F. L. (2020). Assessing the Papuan government's policy for tackling the spread of Coronavirus (COVID-19). Jurnal Ilmu Sosial dan 
Ilmu Politik, 24(1), 48-66. https://doi.org/10.22146/ jsp.56157.

Lazuardi, E. (2020). Pandemic and local measures: Witnessing pandemic in Yogyakarta, Indonesia a city with no lockdown. City and Society, 32(2), 1-17. https://doi.org/10.1111/ciso.12309.

Lim, M. (2013). Many clicks but little sticks: Social media activism in Indonesia. Journal of Contemporary Asia, 43(4), 636-657. https://doi.org/10.1080/00472 336.2013 .769386 .

Lindenbaum, S. (2001). Kuru, prions, and human affairs: Thinking about epidemics. Annual Review of Anthropology, 30, 363-385. https://doi.org/10.1146/ annurev.anthro.30.1.363.

Marisca, D. (2020). Indonesia offers 50 percent off flight tickets to 10 tourist destinations. Retrieved from https://jakartaglobe.id/business/indonesia-offers-50percent-off-flight-tickets-to-10-tourist-destinations.

Miller, D. (2018). Digital anthropology. The Cambridge Encyclopedia of Anthropology, 1-16. https://doi. org/10.29164/18digital.

Miller, D., Costa, E., Haapio-Kirk, L., Haynes, N., Sinanan, J., McDonald, T., Nicolescu, R., Spyer, J., Venkatraman, S., \& Wang, X. (2019). Contemporary comparative anthropology - The why we post project. Ethnos, 84(2), 283-300. https://doi.org/10.1 080/00141844.2017.1397044.

Nadzir, I. (2020). Conspiracy theories and modern disjuncture amidst the spread of COVID-19 in Indonesia. Masyarakat Indonesia, Jurnal Ilmuilmu Sosial Indonesia, 46(2), 150-167. https://doi. org/10.14203/jmi.v46i2.909.

News Desk. (2020). Viral video shows Southeast Sulawesi family unwrapping body of suspected COVID-19 fatality. Retrieved from https://www.thejakartapost. com/news/2020/03/26/viral-video-shows-southeastsulawesi-family-unwrapping-body-of-suspectedcovid-19-fatality.html.

Nicola, M., O’Neill, N., Sohrabi, C., Khan, M., Agha, M., \& Agha, R. (2020). Evidence based management guideline for the COVID-19 pandemic - Review article. International Journal of Surgery, 77, 206216. https://doi.org/10.1016/j.ijsu.2020.04.001.

Nisa, E. F. (2018). Creative and lucrative dawa: The visual culture of Instagram amongst female muslim youth in Indonesia. Asiascape: Digital Asia, 5(1-2), 68-89. https://doi.org/10.1163/22142312-12340085.

Olivia, S., Gibson, J., \& Nasrudin, R. (2020). Indonesia in the time of Covid-19. Bulletin of Indonesian Economic Studies, 56(2), 143-174. https://doi.org/1 $0.1080 / 00074918.2020 .1798581$.

Peckham, R. (2020). The chronopolitics of COVID-19. American Literature, 92(4), 767-779. https://doi. org/10.1215/00029831-8780983.

Perdana, A. (2020). Karantina wilayah di Filipina: Beberapa pelajaran awal untuk mitigasi COVID-19. Retrieved from C:/Users/user/Downloads/CSIS Commentaries_DMRU_014_Perdana.pdf.

Permono, P., Nurish, A., \& Muta'ali, A. (2020). COVID-19: Melacak jejak Islamic state di Indonesia dalam jaringan media sosial. Masyarakat Indonesia:
Majalah Ilmu-Ilmu Sosial Indonesia, 46(2), 138149. https://doi.org/10.14203/jmi.v46i2.903.

Petersen, E., Koopmans, M., Go, U., Hamer, D. H., Petrosillo, N., Castelli, F., Storgaard, M., Al Khalili, S., \& Simonsen, L. (2020). Comparing SARSCoV-2 with SARS-CoV and influenza pandemics. The Lancet Infectious Diseases, 20(9), 238-244. https://doi.org/10.1016/S1473-3099(20)30484-9.

Pitlik, S. D. (2020). COVID-19 compared to other pandemic diseases. Rambam Maimonides Medical Journal, 11(3), 1-17. https://doi.org/10.5041/RMMJ.10418.

Postill, J. (2014). Democracy in an age of viral reality: A media epidemiography of Spain's indignados movement. Ethnography, 15(1), 51-69. https://doi. org/10.1177/1466138113502513.

Postill, J., \& Pink, S. (2012). Social media ethnography: The digital researcher in a messy web. Media International Australia, 145(1), 123-134. https:// doi.org/10.1177\%2F1329878X1214500114.

Purnamasari, R., Sjahrir, B. S., Febriady, A., Farid, M. N., \& Sari, V. A. (2020). Indonesia high-frequency monitoring of Covid-19 impacts. Washington DC: The World Bank.

Riyanto, G. (2020). COVID-19 secrecy in Indonesia. Retrieved from https://www.medizinethnologie.net/ covid-19-secrecy-in-indonesia-witnessing-corona/.

Rosenberg, C. E. (1992). Explaining epidemics. Cambridge: Cambridge University Press. https://doi.org/DOI: 10.1017/CBO9780511666865.

Roth, E. (2020). Epidemic temporalities: A concise literature review. Anthropology Today, 36(4), 13-16. https:// doi.org/10.1111/1467-8322.12590.

Santoso, A. (2020). Acara sepeda Kapolda dikritik, ini penjelasan Polda Sulut. Retrieved from https:// news.detik.com/berita/d-4948992/acara-sepedakapolda-dikritik-ini-penjelasan-polda-sulut.

Scannell, P. (2002). Big brother as a television event. Television \& New Media, 3(3), 271-282. https://doi. org/10.1177/152747640200300303.

Scannell, P. (2018). Media events: An afterword. Culture \& Society, 40(1), 153-157. https://doi. org/10.1177/0163443717726016.

Schmid, C. (2020). The anthropologist amidst and beyond: Notes on temporalities of COVID-19. Social Anthropology, 28(2), 350-351. https://doi. org/10.1111/1469-8676.12893.

Semedi, P. (2021). A power approach and the coronavirus pandemic in Yogyakarta. Humaniora, 33(1), 1-16. https://doi.org/10.22146/jh.62339.

Setiati, S., \& Azwar, M. K. (2020). COVID-19 and Indonesia. Acta Medica Indonesiana - Indonesian Journal Internal Medicine, 52(1), 84-89.

Shaw, R., Kim, Y., \& Hua, J. (2020). Governance, technology and citizen behavior in pandemic: Lessons from COVID-19 in East Asia. Progress in Disaster Science, 6, 100090. https://doi.org/10.1016/j. pdisas.2020.100090.

Slama, M. (2018). Practising Islam through social media in Indonesia. Indonesia and the Malay World, 46(134), 1-4. https://doi.org/10.1080/13639811.2018.141679 8. 
Sparrow, R., Dartanto, T., \& Hartwig, R. (2020). Indonesia under the new normal: Challenges and the way ahead. Bulletin of Indonesian Economic Studies, 56(3), 269-299. https://doi.org/10.1080/00074918.2 020.1854079 .

Yuda, T. K., Damanik, J., \& Nurhadi. (2020). Examining emerging social policy during COVID-19 in Indonesia and the case for a community-based support system. Asia Pacific Journal of Social Work and Development, 31(1-2), 13-22. https://doi.org/10 $.1080 / 02185385.2020 .1829499$.

Zahra, A. A., Purnomo, E. P., \& Kasiwi, A. N. (2020). New democracy in digital era through social media and news online. Humaniora, 11(1), 13-19. https://doi. org/10.21512/humaniora.v11i1.6182.

Zulkaedar, F. (2020). Walikota Prabumulih tidak meliburkan anak sekolah. YouTube. 